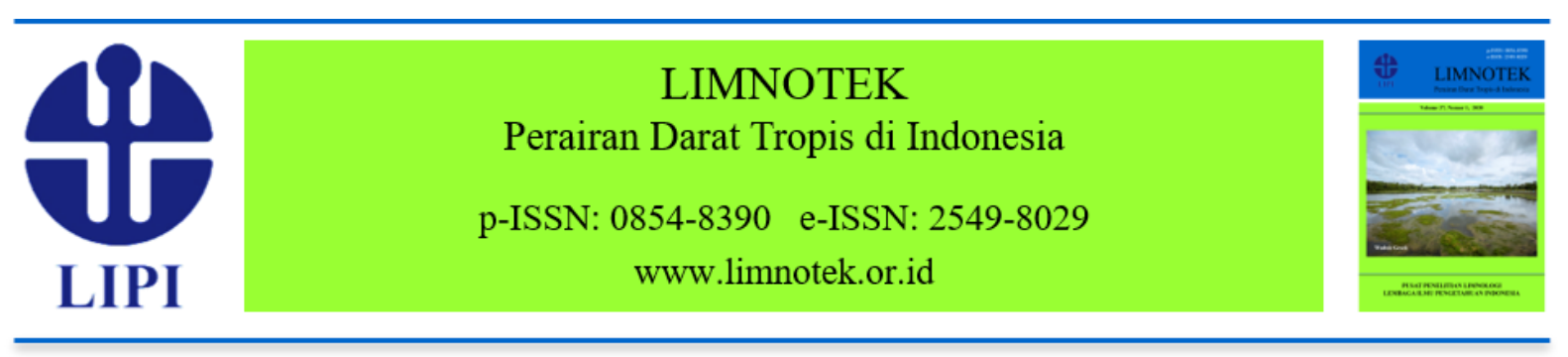

\title{
Kelangsungan Hidup dan Pertumbuhan Ikan Pala Pinang (Desmopuntius pentazona) dalam Wadah Pemeliharaan dengan Warna Berbeda
}

\author{
Pievilya Rahmadhany Kusuma, Eva Prasetiyono, Endang Bidayani
}

Jurusan Akuakultur, Fakultas Pertanian, Perikanan dan Biologi, Universitas Bangka Belitung

Email: evaintegral@gmail.com

Diajukan 8 Agustus 2019. Ditelaah 8 April 2020. Disetujui 24 Juni 2020.

\begin{abstract}
Abstrak
Ikan Pala Pinang (Desmopuntius pentazona) adalah spesies ikan hias air tawar dari Pulau Bangka. Upaya domestikasi ikan ini penting dilakukan seiring dengan peningkatan kerusakan habitat oleh aktivitas penambangan timah. Warna wadah pemeliharaan dapat memengaruhi kelangsungan hidup dan pertumbuhan ikan karena warna wadah menentukan intensitas cahaya yang masuk ke dalam air. Intensitas cahaya dapat memengaruhi kelangsungan hidup dan pertumbuhan ikan karena cahaya berpengaruh pada penglihatan ikan terhadap pakan di dalam air. Tujuan penelitian ini adalah untuk mendapatkan warna wadah terbaik yang mendukung kelangsungan hidup dan pertumbuhan ikan Pala Pinang. Ikan dengan panjang 29,72 $\pm 0,24 \mathrm{~mm}$ dan bobot $0,33 \pm 0,02 \mathrm{~g}$ dipelihara selama 40 hari dalam wadah plastik berukuran $40 \times 30 \times 30$ $\mathrm{cm}^{3}$ yang diisi air $15 \mathrm{~L}$ dan diberi pakan alami berupa larva cacing darah secara ad libitum. Warna wadah yang digunakan dalam penelitian ini adalah transparan, cokelat, merah, dan biru. Hasil penelitian menunjukkan bahwa perbedaan warna wadah pemeliharaan berpengaruh secara signifikan terhadap kelangsungan hidup dan pertumbuhan ikan Pala Pinang. Derajat kelangsungan hidup dalam wadah transparan, cokelat, merah, dan biru masing-masing sebesar $100 \pm 0 ; 83 \pm 7 ; 100 \pm 0$; dan $60 \pm 22 \%$. Laju pertumbuhan spesifik dalam wadah transparan, cokelat, merah, dan biru masing-masing sebesar 0,$011 ; 0,008 ; 0,010$ dan 0,009\%/hari. Laju pertumbuhan bobot mutlak dalam wadah transparan, cokelat, merah, dan biru masing-masing sebesar 0,$43 ; 0,31 ; 0,39$; dan $0,37 \mathrm{~g}$, serta pertumbuhan panjang mutlak dalam wadah transparan, cokelat, merah, dan biru masing-masing sebesar 1,40;0,73;1,22; dan 0,52 mm. Maka, warna wadah transparan dan merah merupakan warna wadah terbaik untuk pemeliharaan ikan Pala Pinang karena kedua perlakuan tersebut secara statistik tidak berbeda nyata dan memiliki nilai yang lebih tinggi untuk semua parameter dibandingkan dua perlakuan lain. Hal ini salah satunya disebabkan oleh intensitas cahaya yang masuk ke wadah transparan dan merah lebih tinggi daripada perlakuan lain, sehingga konsumsi pakan menjadi maksimal dalam mendukung kelangsungan hidup dan pertumbuhan ikan.
\end{abstract}

Kata kunci: ikan Pala Pinang, warna wadah, kelangsungan hidup, laju pertumbuhan spesifik 


\begin{abstract}
Survival and Growth of Fiveband Barb (Desmopuntius pentazona) Reared in Different Color Tanks. Fiveband Barb (Desmopuntius pentazona) is a freshwater ornamental fish species of Bangka Island. Domestication of the fish is important because tin mining activites threaten the fish. One of influencing factors of its survival and growth rate is tank color. Light intensity is one of the environmental factors which significantly affect on survival rate and growth of aquatic organisms. Tank colors may affect light wavelength, while light intensity affects the fish feeding. The purpose of the study was to determine the best tank color for survival rate and growth performance of Fiveband Barb. Tank colors used in this study consisted of transparent, brown, red, and blue. Fiveband Barb with $29.72 \pm 0.24 \mathrm{~mm}$ length and $0.33 \pm 0.02 \mathrm{~g}$ weight were reared in the tanks of $40 \times 30 \times 30 \mathrm{~cm}^{3}$ filled with $15 \mathrm{~L}$ of water and were fed with bloodworm larvae ad libitum. The results showed that tank color gives significant effect $(\mathrm{P}<0.05)$ on the survival rate of the fish where in transparent, brown, red, and blue tanks they were $100 \pm 0 ; 83 \pm 7 ; 100 \pm 0$; dan $60 \pm 22 \%$, respectively. Spesific growth rate in transparent, brown, red, and blue tanks were $0.011 ; 0.008 ; 0.010$; and $0,009 \% /$ day, respectively. Absolute weight growth rate in transparent, brown, red, and blue tanks were 0,43;0,31;0,39; dan $0,37 \mathrm{~g}$, respectively, while absolute length growth rate in transparent, brown, red, and blue tanks were 1,$40 ; 0,73 ; 1,22$; dan $0,52 \mathrm{~mm}$, respectively. Therefore, the transparent and red tanks were the best tank colors for Fiveband Barb culture. This is presumably because the light intensity entering the transparent and red tanks was higher than the other two colors so as to maximize feed consumption in supporting the survival and growth of the fish.
\end{abstract}

Keywords: Fiveband Barb, tank colors, survival rate, specific growth rate

\section{Pendahuluan}

Ikan hias merupakan salah satu komoditas perikanan yang diminati oleh pasar dalam maupun luar negeri. Selama kurun waktu 2012 hingga 2018, produksi ikan hias nasional tumbuh rata-rata sebesar $5,05 \%$ per tahun. Produksi ikan hias pada tahun 2012 mencapai 938,47 juta ekor dan naik menjadi 1,19 miliar ekor pada tahun 2018 (Soebjakto, 2020). Indonesia memiliki 450 spesies ikan hias dari 1.110 spesies ikan air tawar di dunia dan 400 spesies telah diperdagangkan (Suhana, 2017).

Salah satu spesies ikan hias yang terdapat di perairan rawa gambut di Pulau Bangka adalah ikan Pala Pinang (Desmopuntius pentazona). Menurut Froese dan Pauly (2016) dalam USFWS (2018), di habitat aslinya ikan Pala Pinang hidup dalam kisaran $\mathrm{pH}$ 5,0-6,0. Saat ini, ikan Pala Pinang semakin sulit ditemukan. Dampak kerusakan ekosistem perairan akibat kegiatan penambangan timah yang dilakukan masyarakat menjadikan keberadaan ikan-ikan lokal di Pulau Bangka terancam (Muslih et al., 2014). Maka, domestikasi merupakan salah satu upaya untuk mencegah kepunahan spesies ikan ini. Selain itu, domestikasi ikan Pala Pinang perlu dilakukan untuk mengembangkan ikan hias lokal yang potensial untuk dikomersialkan.

Dalam proses domestikasi, beberapa faktor lingkungan perlu diperhatikan untuk mendukung kehidupan ikan di dalam wadah pemeliharaan. Salah satunya yaitu warna wadah pemeliharaan yang dapat menentukan intensitas cahaya dalam air media pemeliharaan karena terkait dengan penyerapan, pemantulan, dan pembiasan cahaya yang akan memengaruhi beberapa tingkah laku ikan seperti rangsangan untuk makan, melindungi diri, dan rangsangan untuk mendekati cahaya (Baskoro \& Efendy, 2005). Ikan memerlukan cahaya yang cukup untuk dapat mendeteksi dan menangkap pakan. Namun, intensitas 
cahaya yang terlalu tinggi dapat mengakibatkan stres, bahkan kematian pada ikan (Boeuf \& Bail, 1999). Selain itu, sensitivitas penglihatan ikan dipengaruhi oleh berbagai faktor seperti jarak penglihatan, warna dan corak objek, serta kekontrasan dan kemampuan membedakan objek yang bergerak (Fujaya, 2008).

Pada vertebrata, pigmentasi kulit bisa diubah dengan stimulasi hormonal dan warna dari latar belakang wadah pemeliharaan sebagai faktor-faktor penentu untuk intensitas dan pola pigmentasi kulit (Imanpoor \& Abdollahi, 2011). Ikan yang dipelihara pada kondisi terang akan memberikan reaksi warna kulit yang lebih cerah dan menarik, berbeda dari ikan yang dipelihara di tempat gelap karena ada perbedaan reaksi melanosom yang mengandung pigmen melanofor terhadap rangsangan warna cahaya (Said et al., 2005). Warna wadah pemeliharaan akan memengaruhi intensitas cahaya dan panjang gelombang yang dipantulkan kembali. Kondisi ini dapat memengaruhi pertumbuhan dan kelangsungan hidup ikan (Subiyanto et al., 2013). Oleh karena itu, penelitian ini bertujuan untuk mengetahui pengaruh berbagai warna wadah pemeliharaan terhadap kelangsungan hidup dan pertumbuhan ikan Pala Pinang, serta untuk mendapatkan warna wadah pemeliharaan terbaik.

\section{Bahan dan Metode}

Penelitian ini dilaksanakan pada bulan Januari-Maret 2019 di Laboratorium Akuakultur, Fakultas Pertanian, Perikanan, dan Biologi, Universitas Bangka Belitung. Wadah yang digunakan untuk memelihara ikan yaitu 12 bak plastik berukuran $40 \times 30$ $\times 30 \mathrm{~cm}^{3}$. Wadah terlebih dahulu dibersihkan dan setelah dikeringkan dilapisi dengan plastik berwarna. Selanjutnya, wadah diisi air sebanyak $15 \mathrm{~L}$ dan diaerasi.

Air yang digunakan dalam penelitian ini adalah air sumur yang ditampung dalam tandon. Ikan Pala Pinang yang diteliti berjumlah 96 ekor dengan panjang rata-rata $29,72 \pm 0,24 \mathrm{~mm}$ (Gambar 1) yang diukur menggunakan jangka sorong digital dan bobot rata-rata $0,33 \pm 0,02 \mathrm{~g}$ yang diukur menggunakan timbangan digital. Pakan berupa larva cacing darah (Chironomus sp.) diberikan sebanyak tiga kali sehari dengan metode pemberian pakan secara ad libitum.

Pengukuran suhu dan $\mathrm{pH}$ dilakukan setiap hari pada pukul 08.00 dan 15.00 selama penelitian dengan menggunakan termometer dan $\mathrm{pH}$ meter. Parameter oksigen terlarut (DO) diukur pada pukul 08.00 dan 15.00 setiap 10 hari sampai akhir penelitian dengan menggunakan DO meter, sedangkan nitrogen amonia total (TAN) dan kesadahan diukur pada awal dan akhir penelitian pada pukul 08.00 dan 15.00 dengan menggunakan metode titrasi. Parameter kecerahan warna tubuh ikan diukur pada awal dan akhir pemeliharaan dengan cara ikan difoto menggunakan kamera DSLR, kemudian nilai RGB hasil foto diukur menggunakan Adobe Photoshop.

Penelitian ini menggunakan metode eksperimen dengan Rancangan Acak Lengkap (RAL). Perlakuan pada penelitian ini adalah penggunaan empat warna wadah yang berbeda, yaitu transparan, cokelat, merah, dan biru, yang diulang sebanyak tiga kali. Penelitian ini dilakukan selama 40 hari dan pertumbuhan serta kelangsungan hidup ikan diamati pada awal dan akhir penelitian.

Parameter utama yang diamati yaitu kelangsungan hidup, laju pertumbuhan spesifik, pertumbuhan bobot mutlak, dan pertumbuhan panjang mutlak. Parameter pendukung yang diamati yaitu tingkat konsumsi pakan, kecerahan warna tubuh ikan, dan kualitas air. Rumus yang digunakan untuk menghitung parameter utama adalah sebagai berikut:

Tingkat kelangsungan hidup dihitung menurut Effendie (2002):

$\mathrm{SR}=\frac{\mathrm{N}_{\mathrm{t}}}{\mathrm{N}_{0}} \times 100$

Keterangan:

$\mathrm{SR}=$ Tingkat kelangsungan hidup (\%)

$\mathrm{N}_{0}=$ Jumlah ikan yang ditebar pada awal penelitian (ekor) 


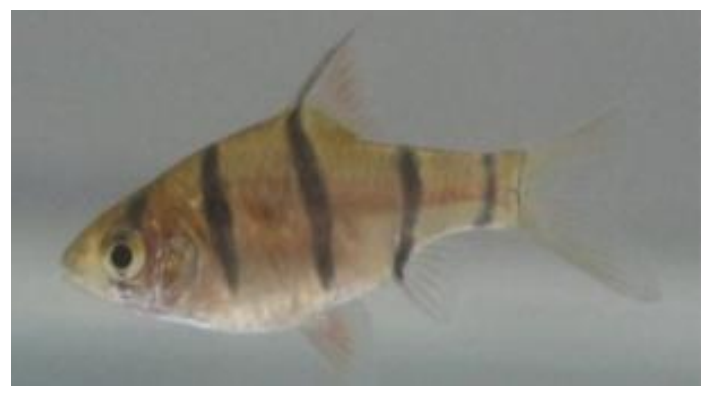

Gambar 1. Ikan Pala Pinang yang digunakan dalam penelitian ini

$\mathrm{N}_{\mathrm{t}}=\begin{aligned} & \text { Jumlah ikan yang hidup pada akhir } \\ & \text { penelitian (ekor) }\end{aligned}$ Laju pertumbuhan spesifik (Specific Growth Rate, SGR) merupakan laju pertumbuhan bobot individu yang dihitung berdasarkan Zonneveld et al. (1991):

$\mathrm{SGR}=\frac{\operatorname{Ln} \mathrm{W}_{\mathrm{t}}-\operatorname{Ln} \mathrm{W}_{0}}{\mathrm{t}} \times 100$

Keterangan:

SGR = Laju pertumbuhan spesifik (\%/hari)

$\mathrm{W}_{\mathrm{t}}=$ Bobot rata-rata ikan pada akhir penelitian $(\mathrm{g})$

$\mathrm{W}_{0}=$ Bobot rata-rata ikan pada awal penelitian $(\mathrm{g})$

$\mathrm{t}=$ Lama pemeliharaan (hari)

Pertumbuhan bobot mutlak (PBM) ikan Pala Pinang diukur menggunakan timbangan digital. Pertumbuhan bobot mutlak dihitung berdasarkan Effendie (2002):

$\Delta \mathrm{W}=\mathrm{W}_{\mathrm{t}}-\mathrm{W}_{0}$

Keterangan:

$\Delta \mathrm{W}=$ Pertumbuhan bobot mutlak $(\mathrm{g})$

$\mathrm{W}_{\mathrm{t}}=$ Bobot ikan rata-rata pada akhir penelitian $(\mathrm{g})$

$\mathrm{W}_{0}=$ Bobot ikan rata-rata pada awal penelitian $(\mathrm{g})$

Pertumbuhan panjang mutlak (PPM) adalah selisih panjang akhir dan panjang awal ikan selama pemeliharaan. Pertumbuhan panjang mutlak dihitung berdasarkan Effendi (2002): $\mathrm{PPM}=\mathrm{L}_{\mathrm{t}}-\mathrm{L}_{0}$

Keterangan:

PPM = Pertumbuhan panjang mutlak $(\mathrm{mm})$

$\mathrm{L}_{\mathrm{t}} \quad=$ Panjang akhir rata-rata $(\mathrm{mm})$

$\mathrm{L}_{0} \quad=$ Panjang awal rata-rata $(\mathrm{mm})$

Penghitungan tingkat konsumsi pakan berdasarkan Zonneveld et al. (1991) sebagai berikut:
$\mathrm{FC}=\mathrm{F}_{0}-\mathrm{F}_{\mathrm{t}}$

Keterangan:

$\mathrm{FC}=$ Konsumsi Pakan $(\mathrm{g})$

$\mathrm{F}_{0}=$ Berat pakan awal $(\mathrm{g})$

$\mathrm{F}_{\mathrm{t}}=$ Berat pakan akhir $(\mathrm{g})$

Data yang diperoleh dianalisis menggunakan Analisis Ragam (ANOVA) untuk mengetahui pengaruh perlakuan yang diberikan terhadap kelangsungan hidup dan pertumbuhan ikan. Apabila terdapat perbedaan antara perlakuan, maka uji lanjut Beda Nyata Jujur akan dilakukan untuk melihat perlakuan terbaik.

\section{Hasil}

\section{Kelangsungan Hidup}

Hasil penelitian ini menunjukkan bahwa perbedaan warna wadah pemeliharaan berpengaruh terhadap kelangsungan hidup ikan Pala Pinang yang dipelihara. Persentase kelangsungan hidup ikan selama pemeliharaan ditunjukkan dalam Gambar 2.

Hasil analisis ragam menunjukkan bahwa warna wadah yang berbeda memberikan pengaruh yang berbeda nyata terhadap kelangsungan hidup ikan Pala Pinang. Perlakuan warna wadah dengan kelangsungan hidup tertinggi (100\%) ditunjukkan oleh wadah transparan dan merah. Kedua perlakuan tersebut tidak berbeda nyata dari perlakuan warna wadah cokelat, namun berbeda nyata dari perlakuan warna wadah biru (Gambar 2). 


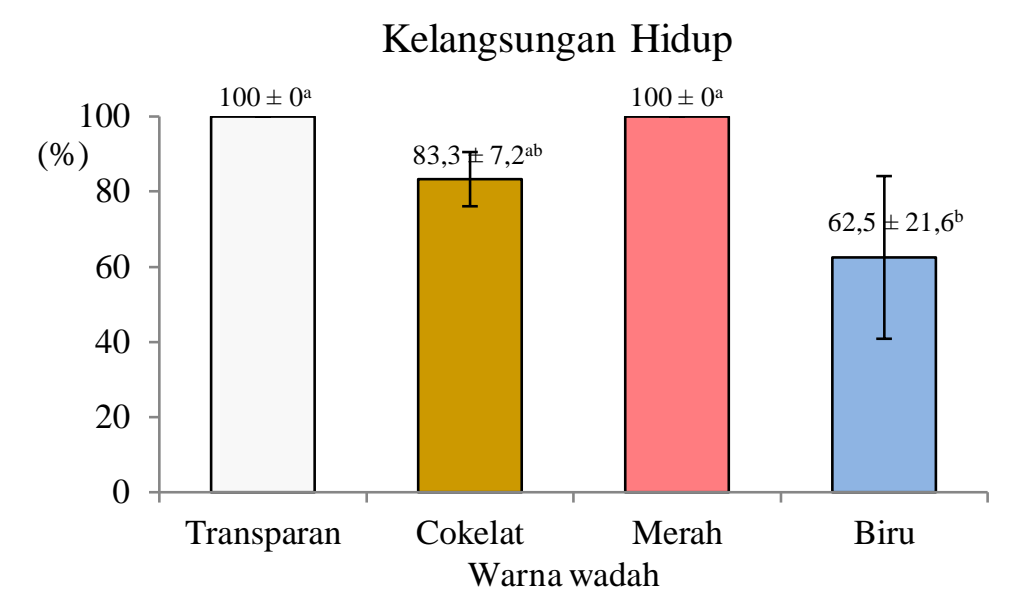

Keterangan: Huruf superskrip yang berbeda menunjukkan pengaruh yang berbeda nyata antarperlakuan $(\mathrm{P}<0,05)$.

Gambar 2. Kelangsungan hidup ikan Pala Pinang

Perlakuan warna wadah cokelat $(83,3 \%)$ tidak berbeda nyata dari perlakuan warna wadah biru yang merupakan perlakuan dengan tingkat kelangsungan hidup terendah $(62,5 \%)$.

\section{Laju Pertumbuhan Spesifik}

Perlakuan warna wadah yang berbeda juga berpengaruh terhadap laju pertumbuhan spesifik ikan Pala Pinang (Gambar 3).

Hasil analisis ragam menunjukkan bahwa warna wadah yang berbeda mengha- silkan laju pertumbuhan spesifik yang berbeda. Laju pertumbuhan spesifik tertinggi ditunjukkan oleh perlakuan warna wadah transparan $(0,011 \%$ /hari). Perlakuan tersebut tidak berbeda nyata dari perlakuan warna wadah merah dan biru. Perlakuan warna wadah cokelat merupakan perlakuan dengan laju pertumbuhan spesifik terendah $(0,008 \%$ /hari). Perlakuan warna wadah cokelat tidak berbeda nyata dari warna wadah merah dan biru.

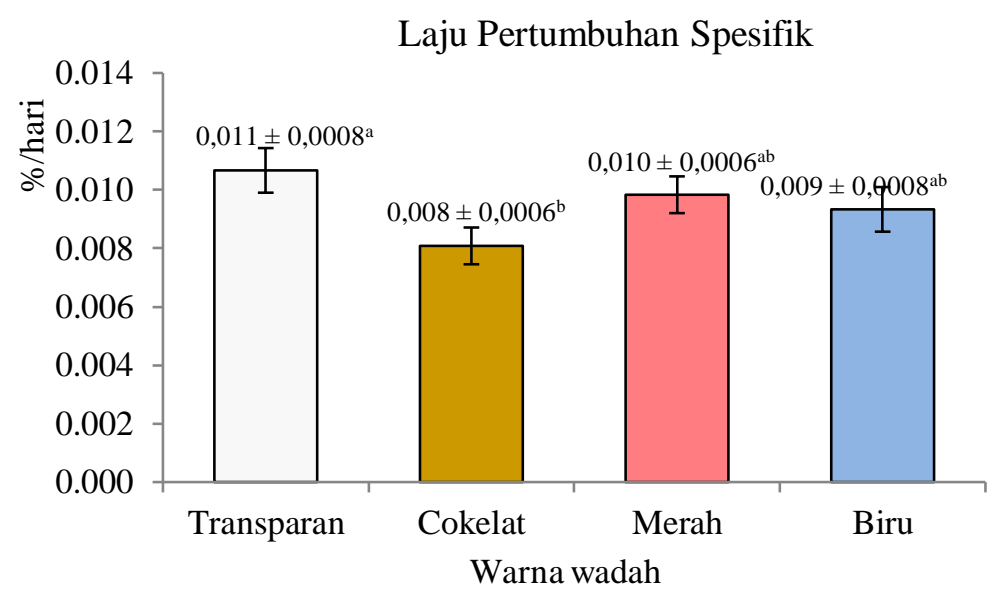

Keterangan: Huruf superskrip yang berbeda menunjukkan pengaruh yang berbeda nyata antarperlakuan $(\mathrm{P}<0,05)$.

Gambar 3. Laju pertumbuhan spesifik ikan Pala Pinang 
Pertumbuhan Bobot Mutlak (PBM)

Pengaruh warna wadah pemeliharaan yang berbeda terhadap pertumbuhan bobot mutlak ikan Pala Pinang diperlihatkan dalam Gambar 4.

Hasil analisis ragam menunjukkan bahwa perlakuan warna wadah yang berbeda menghasilkan pertumbuhan bobot mutlak yang berbeda nyata antara perlakuan. Pertumbuhan bobot mutlak tertinggi didapatkan dari perlakuan warna wadah transparan $(0,43 \mathrm{~g})$. Perlakuan tersebut tidak berbeda nyata dari perlakuan warna wadah merah dan biru. Pertumbuhan bobot mutlak terendah didapatkan dari perlakuan warna wadah cokelat $(0,34 \mathrm{~g})$ yang tidak berbeda nyata dari perlakuan warna wadah merah dan biru.

\section{Pertumbuhan Panjang Mutlak (PPM)}

Pertumbuhan panjang mutlak ikan Pala Pinang selama 40 hari penelitian bergantung pada warna wadah pemeliharaan yang berbeda-beda (Gambar 5).

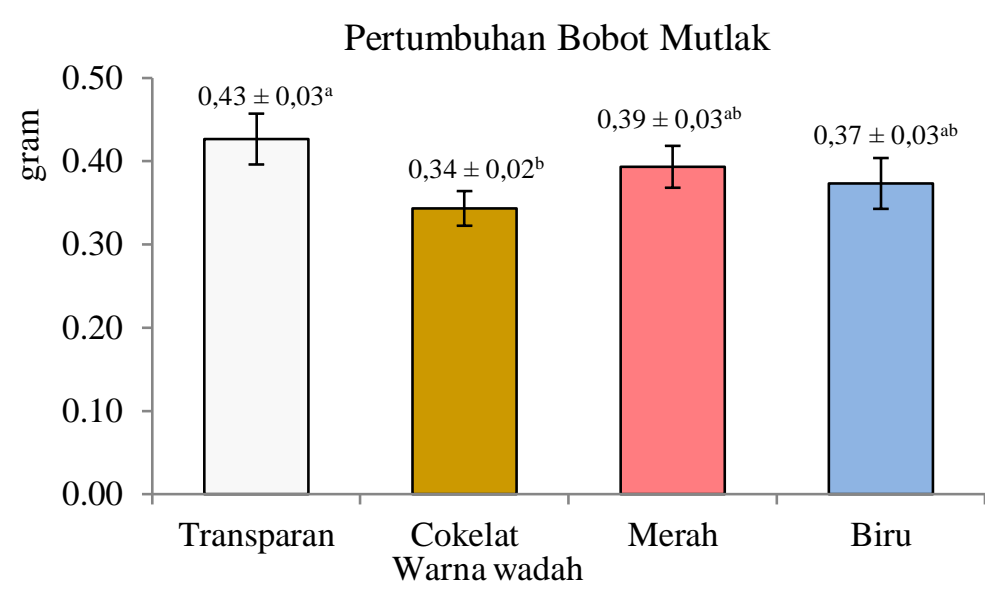

Keterangan: Huruf superskrip yang berbeda menunjukkan pengaruh yang berbeda nyata antarperlakuan $(\mathrm{P}<0,05)$.

Gambar 4. Pertumbuhan bobot mutlak (PBM) ikan Pala Pinang

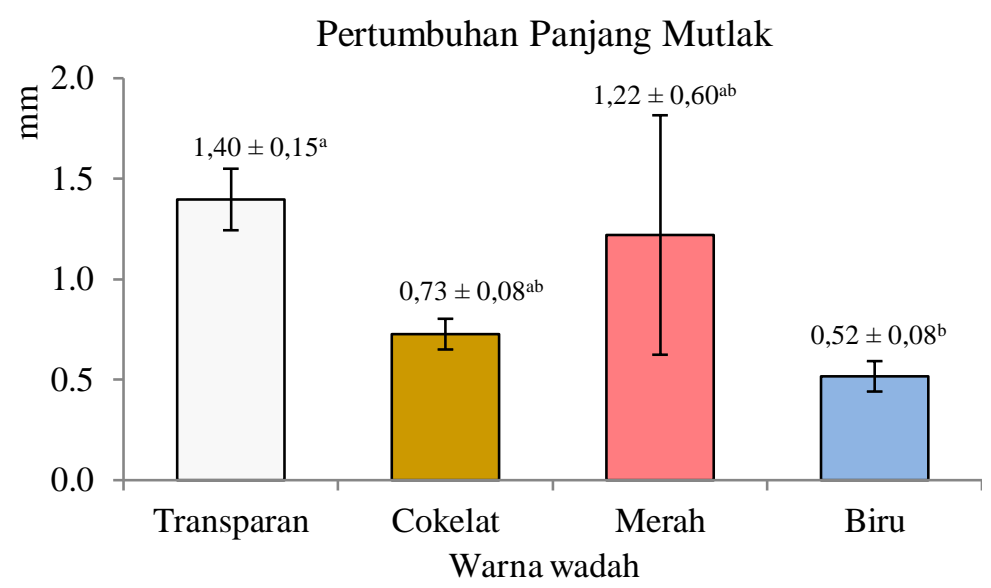

Keterangan: Huruf superskrip yang berbeda menunjukkan pengaruh yang berbeda nyata antarperlakuan $(\mathrm{P}<0,05)$.

Gambar 5. Pertumbuhan Panjang Mutlak (PPM) ikan Pala Pinang 
Hasil analisis ragam menunjukkan bahwa perlakuan warna wadah transparan menghasilkan pertumbuhan panjang mutlak tertinggi $(1,40 \mathrm{~mm})$. Namun, perlakuan tersebut tidak berbeda nyata dari perlakuan warna wadah cokelat dan merah. Perlakuan warna wadah biru merupakan perlakuan dengan pertumbuhan panjang mutlak terendah $(0,52 \mathrm{~mm})$. Namun, perlakuan ini tidak berbeda nyata dari perlakuan warna wadah cokelat dan merah.

\section{Tingkat Konsumsi Pakan}

Tingkat konsumsi pakan ikan Pala Pinang selama penelitian bergantung pada warna wadah pemeliharaan yang berbedabeda (Gambar 6). Perlakuan warna wadah pemeliharaan yang berbeda-beda memengaruhi tingkat konsumsi pakan ikan Pala
Pinang. Tingkat konsumsi pakan tertinggi diperoleh dari perlakuan warna wadah transparan, yaitu $0,895 \mathrm{~g}$ yang tidak berbeda nyata dari perlakuan warna wadah cokelat dan merah. Tingkat konsumsi pakan terendah yaitu $0,409 \mathrm{~g}$ diperoleh dari perlakuan warna wadah biru yang tidak berbeda nyata dari perlakuan warna wadah cokelat dan merah.

\section{Kecerahan Warna Ikan}

Perlakuan warna wadah pemeliharaan yang berbeda menghasilkan kecerahan warna ikan Pala Pinang yang berbeda (Tabel 1). Perubahan Red Green Blue (RGB) pada setiap perlakuan menunjukkan hasil yang berbeda nyata antara perlakuan.

Tingkat Konsumsi Pakan

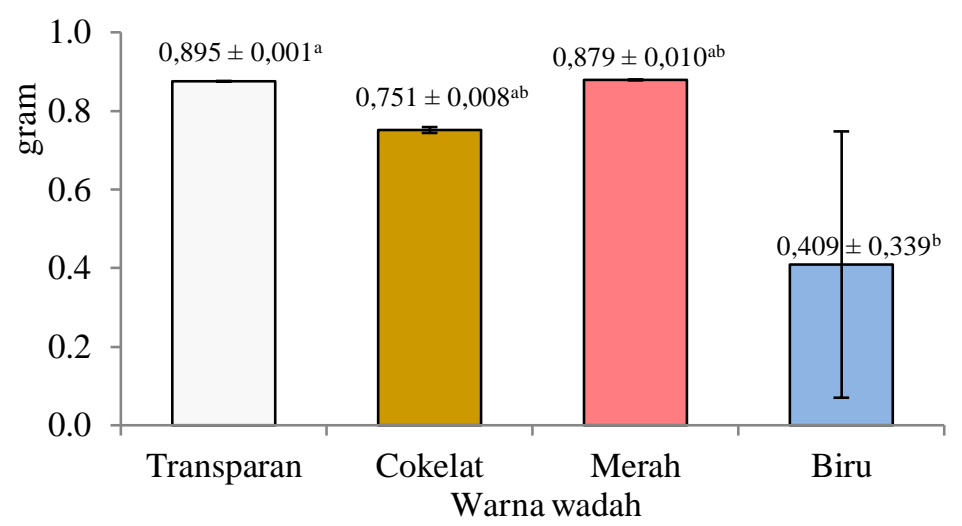

Keterangan: Huruf superskrip yang berbeda menunjukkan pengaruh yang berbeda nyata antarperlakuan $(\mathrm{P}<0,05)$.

Gambar 6. Tingkat konsumsi pakan ikan Pala Pinang

Tabel 1. Perubahan kecerahan warna ikan Pala Pinang

\begin{tabular}{lccc}
\hline Perlakuan & $\begin{array}{c}\text { RGB awal } \\
\text { rata-rata }\end{array}$ & $\begin{array}{c}\text { RGB akhir } \\
\text { rata-rata }\end{array}$ & $\begin{array}{c}\text { Perubahan RGB } \\
\text { selama pemeliharaan }\end{array}$ \\
\hline Transparan & 328,11 & 347,33 & $19,22 \pm 6,17^{\mathrm{a}}$ \\
Cokelat & 329,33 & 340,33 & $11,00 \pm 0,33^{\mathrm{ab}}$ \\
Merah & 315,33 & 330,45 & $15,12 \pm 3,35^{\text {ab }}$ \\
Biru & 325,89 & 334,33 & $8,44 \pm 3,57^{\mathrm{b}}$ \\
\hline
\end{tabular}

Keterangan: Huruf superskrip yang berbeda menunjukkan pengaruh yang berbeda nyata antarperlakuan $(\mathrm{P}<0,05)$. 
Perlakuan warna wadah yang berbeda memengaruhi kecerahan warna tubuh ikan Pala Pinang. Kecerahan warna tertinggi didapatkan dari perlakuan warna wadah transparan dengan nilai perubahan RGB selama pemeliharaan sebesar 19,22. Perlakuan tersebut tidak berbeda nyata dari perlakuan warna wadah cokelat dan merah. Kecerahan warna terendah diperoleh dari perlakuan warna wadah biru, dengan nilai perubahan RGB sebesar 8,44. Perlakuan warna wadah biru tidak berbeda nyata dari perlakuan warna wadah cokelat dan merah.

\section{Kualitas Air}

Hasil pengukuran kualitas air selama penelitian ditunjukkan dalam Tabel 2.

\section{Pembahasan}

Kelangsungan hidup yang rendah pada ikan yang dipelihara dalam wadah biru diduga karena ikan mengalami stres, sehingga nafsu makan ikan menurun dan ikan mengalami kematian. Dalam beradaptasi dengan lingkungan, ikan menggunakan alat penerima rangsang seperti mata yang merekam perubahan cahaya, yang selanjutnya disampaikan ke otak untuk melakukan adaptasi (Fujaya, 2008). Wadah pemeliharaan dengan warna terang akan memantulkan cahaya ke perairan yang menyebabkan kondisi terang pada perairan, sehingga pakan mudah terlihat dan ditemukan ikan. Selain itu, warna wadah dan intensitas cahaya juga memengaruhi laju pertumbuhan panjang dan bobot ikan (Rahmawati et al., 2016). Pratama et al. (2018) menyatakan bahwa warna tangki dan intensitas cahaya memengaruhi kecerahan warna pada ikan.

Ikan yang dipelihara dalam wadah transparan memperlihatkan kelangsungan hidup, laju pertumbuhan spesifik, pertumbuhan bobot mutlak, pertumbuhan panjang mutlak, tingkat konsumsi pakan, dan peningkatan nilai RGB tertinggi, diikuti oleh ikan yang dipelihara dalam wadah merah. Hal ini menunjukkan bahwa pada kedua warna wadah ini, ikan dapat beradaptasi lebih cepat karena intensitas cahaya yang lebih tinggi membuat lingkungan menjadi lebih terang dan ikan lebih peka atau sensitif terhadap keberadaan makanan. Selain itu, spektrum warna putih dalam wadah transparan dan warna merah dalam wadah merah yang ditangkap mata ikan membuat ikan lebih mudah mendeteksi keberadaan pakan karena lingkungan yang lebih terang tersebut. Kondisi yang berbeda terjadi dalam wadah cokelat dan biru. Ikan mengalami proses adaptasi yang lambat karena warna wadah cokelat dan biru membuat intensitas cahaya menjadi lebih rendah. Akibatnya, ikan memerlukan waktu yang lebih lama dalam beradaptasi dengan kondisi kurang terang tersebut untuk mampu mendeteksi keberadaan pakan. Kemampuan ikan untuk tertarik pada suatu sumber cahaya berbeda-beda. Cahaya yang memiliki intensitas dan panjang gelombang tertentu akan memengaruhi pergerakan dan tingkah laku ikan secara langsung atau tidak langsung (Nurdin, 2013).

Tabel 2. Kualitas air pemeliharaan ikan Pala Pinang

\begin{tabular}{lccccc}
\hline \multicolumn{1}{c}{ Parameter } & $\begin{array}{c}\text { Wadah } \\
\text { transparan }\end{array}$ & $\begin{array}{c}\text { Wadah } \\
\text { cokelat }\end{array}$ & $\begin{array}{c}\text { Wadah } \\
\text { merah }\end{array}$ & Wadah biru & $\begin{array}{c}\text { Sungai } \\
\text { (habitat asli) }\end{array}$ \\
\hline Suhu $\left({ }^{\circ} \mathrm{C}\right)$ & $28,25 \pm 0,92$ & $28,25 \pm 0,93$ & $28,25 \pm 0,94$ & $28,25 \pm 0,95$ & 26,8 \\
pH & $6,75 \pm 0,35$ & $6,65 \pm 0,49$ & $6,65 \pm 0,50$ & $6,65 \pm 0,51$ & 5,5 \\
DO $(\mathrm{mg} / \mathrm{L})$ & $4,83 \pm 0,73$ & $4,62 \pm 0,52$ & $4,64 \pm 0,48$ & $4,68 \pm 0,78$ & 3,84 \\
Kesadahan $(\mathrm{mg} / \mathrm{L})$ & $24,25 \pm 0,35$ & $20,25 \pm 6,01$ & $22,25 \pm 3,18$ & $19,75 \pm 6,72$ & 24,5 \\
TAN $(\mathrm{mg} / \mathrm{L})$ & $1,61 \pm 1,13$ & $1,86 \pm 1,31$ & $1,78 \pm 1,25$ & $1,72 \pm 1,22$ & 2,80 \\
\hline
\end{tabular}


Perbedaan warna wadah pemeliharaan memengaruhi tingkat kelangsungan hidup ikan karena ikan membutuhkan intensitas cahaya yang cukup untuk perkembangan secara normal dan pada intensitas cahaya yang rendah perkembangan ikan akan terganggu (Nurdin et al., 2015).

Secara umum, warna lingkungan berpengaruh terhadap mortalitas dan pertumbuhan ikan (Nurhidayat et al., 2017). Selain itu, rangsangan warna memberikan peranan penting dalam pola makan ikan. Warna lingkungan berpengaruh terhadap kemampuan ikan dalam mendeteksi makanan (Hoar et al., 1979). Wadah transparan mampu memaksimalkan konsumsi pakan karena pakan terlihat kontras. Sulistyaningrum (2006) menunjukkan bahwa pakan dengan kekontrasan yang tinggi memiliki peluang untuk dikonsumsi delapan kali lebih besar daripada pakan dengan kekontrasan rendah. Selama pemeliharaan, ikan Pala Pinang diberi pakan berupa larva cacing darah (Chironomus sp.) yang berwarna merah. Saat dipadukan dengan wadah transparan yang memberikan kondisi terang, pakan akan terlihat dengan mudah oleh ikan.

Ikan Pala Pinang yang dipelihara dalam wadah cokelat memiliki laju pertumbuhan spesifik terendah, sebesar 0,008\%/hari. Dalam wadah ini, kemampuan ikan dalam menangkap pakan yang diberikan rendah. Warna cokelat termasuk warna yang meredam cahaya, sehingga cahaya yang masuk ke dalam wadah pemeliharan kurang. Cahaya yang kurang atau teredam mengakibatkan penurunan penglihatan ikan terhadap pakan karena kekontrasan pakan melemah, sehingga pakan menjadi kurang menarik bagi ikan (Fitch \& Lankford, 2013).

Warna dapat memengaruhi mekanisme fisiologis ikan melalui rangsangan panjang gelombang yang diterima oleh reseptor cahaya pada mata. Rangsangan tersebut diteruskan ke sistem saraf pusat, kemudian sistem saraf pusat akan mengirimkan sinyal ke mata untuk memolarisasikan cahaya menurut perbedaan rangsangannya (Husni, 2002). Perbedaan tingkat rangsangan memberikan pengaruh atau respons yang berbeda secara biologis, antara lain terhadap aktivitas pergerakan dan reproduksi. Salah satunya adalah pergerakan dalam mencari makanan. Hasil penelitian Strand et al. (2007) menunjukkan bahwa warna wadah dan intensitas cahaya merupakan faktor penting untuk dipertimbangkan dalam memaksimalkan asupan pakan dan laju pertumbuhan ikan.

Hubungan berat dapat dianggap sebagai suatu fungsi dari panjang (Effendie, 2002). Selama pemeliharaan, pertumbuhan panjang dan berat ikan dalam wadah transparan dan wadah merah menunjukkan perbandingan yang linier sampai akhir pemeliharaan. Strand et al. (2007) menyatakan bahwa pemanfaatan pakan yang tinggi sesuai dengan kebutuhan ikan yang dipelihara akan meningkatkan pertumbuhan. Penggunaan warna wadah yang terang membuat pakan yang diberikan lebih terlihat, sehingga daya konsumsi pakan akan lebih tinggi dibanding wadah gelap.

Tingkat konsumsi pakan yang tinggi pada perlakuan wadah transparan dan wadah merah diduga karena intensitas cahaya yang masuk lebih tinggi, sehingga pakan dapat dikonsumsi langsung oleh ikan. Nurhidayat et al. (2017) menyatakan bahwa warna lingkungan berpengaruh terhadap rangsangan dan berperan penting dalam pola makan ikan karena warna lingkungan memengaruhi kemampuan ikan dalam mendeteksi makanan (Hoar et al., 1979).

Pakan larva cacing darah yang berwarna merah dapat dilihat dengan baik dalam wadah transparan dan wadah merah karena kedua wadah dapat langsung meneruskan cahaya, sehingga lingkungan menjadi lebih terang dan tingkat konsumsi pakan tertinggi. Kimbal (1998) menyatakan bahwa sel kerucut pada retina mata ikan yang dapat membuat ikan melihat warnawarna hanya bekerja pada cahaya terang.

Tingkat konsumsi pakan dan kecerahan warna ikan Pala Pinang dalam wadah biru merupakan yang terendah dibandingkan dengan yang lain. Pengamatan 
tingkah laku ikan dalam wadah biru yang lebih sering bersembunyi di dekat batu aerasi menandakan ikan dalam keadaan stres. Nafsu makan ikan yang stres akan menurun, sehingga ikan menjadi lemah (Boyd, 1998). Selain itu, warna badan ikan saat mengalami stres akan cenderung memucat (Rahmawati et al., 2016).

Ikan yang dipelihara pada kondisi terang akan memberikan reaksi warna berbeda dari ikan yang dipelihara pada tempat gelap karena reaksi melanosom yang mengandung pigmen melanofor terhadap rangsangan yang ada (Said et al., 2005). Kondisi tempat pemeliharaan yang terang memberikan penampilan warna yang lebih baik dibandingkan kondisi tempat pemeliharaan yang gelap karena pada kondisi cahaya terang melanofor menjadi terkonsentrasi di sekitar nukleus, sel berkerut, dan membuat kulit ikan lebih cemerlang (Storebaken \& Hong, 1992).

Faktor lingkungan seperti kualitas air dapat memengaruhi kelangsungan hidup dan nafsu makan ikan yang dipelihara. Nilai ratarata suhu, $\mathrm{pH}$, oksigen terlarut (DO), kesadahan, dan nitrogen ammonia total (TAN) selama pemeliharaan ikan Pala Pinang dalam berbagai warna wadah yang berbeda menunjukkan nilai yang tidak berbeda nyata dari nilai kualitas air di habitat alaminya. Perbedaan nilai kualitas perairan masih dalam batas toleransi dan bisa diadaptasi oleh ikan. Nilai kesadahan pada semua perlakuan juga terlihat tidak berbeda nyata dari nilai kesadahan habitat ikan di sungai. Nilai suhu dan $\mathrm{pH}$ pada semua perlakuan berbeda dari di habitat aslinya, nilai DO dan TAN lebih baik daripada nilainya di habitat sungai, namun ikan Pala Pinang memiliki toleransi terhadap perbedaan nilai tersebut. Kualitas air yang baik untuk kehidupan ikan ditandai dengan kandungan oksigen yang cukup dan kadar buangan metabolit (amonia) yang rendah (Bhatnagar \& Devi, 2013). Secara umum, kondisi kualitas air selama penelitian mendukung kehidupan ikan Pala Pinang.

\section{Kesimpulan}

Warna wadah pemeliharan berpengaruh nyata terhadap kelangsungan hidup dan pertumbuhan ikan Pala Pinang. Wadah transparan dan wadah merah merupakan wadah pemeliharaan terbaik untuk ikan Pala Pinang. Kedua perlakuan tersebut secara statistik tidak berbeda nyata. Intensitas cahaya berperan dalam mendukung kelangsungan hidup, laju pertumbuhan spesifik, laju pertumbuhan bobot mutlak, dan pertumbuhan panjang mutlak karena intensitas cahaya yang tinggi dalam wadah transparan dan wadah merah menghasilkan lingkungan yang lebih terang dan meningkatkan sensitivitas ikan dalam mendeteksi pakan.

\section{Ucapan Terima Kasih}

Penelitian ini difasilitasi dan dibantu pendanaannya oleh Jurusan Akuakultur, Universitas Bangka Belitung dalam Program riset ikan-ikan lokal Bangka Belitung 2019. Ucapan terima kasih disampaikan kepada Laboratorium Jurusan Akuakultur, Universitas Bangka Belitung dan UPTD Laboratorium Lingkungan Hidup Provinsi Kepulauan Bangka Belitung yang telah membantu dan memfasilitasi pengukuran kualitas air selama penelitian.

\section{Referensi}

Bhatnagar A, Devi P. 2013. Water Quality Guidelines for the Management of Pond Fish Culture. International Journal of Evironmental Sciences 3(6): 198-2009

Baskoro MS, Effendy A. 2005. Tingkah Laku Ikan: hubungan dengan metode pengoperasian alat tangkap ikan. Bogor: Institut Pertanian Bogor

Boeuf G, Bail PYL. 1999. Does light have an influence on fish growth? Aquaculture 177 (1-4): 129-152 
Boyd CE. 1992. Water Quality in Pond Aquaculture. Alabama: Birmigham Publishing Co

Effendie MI. 2002. Biologi Perikanan. Yayasan Pusaka Utama. Bogor

Fitch T, Lankford D. 2013. Black Material Absorb Light and White Material Reflect It. Mu's Office of Science Outreach

Fujaya Y. 2008. Fisiologi Ikan. Jakarta: Rineka Cipta

Hoar WS, Randall DJ, Brett JR. 1979. Fish Physiology: Bioenergetic and Growth. San Diego: Academic Press, Inc

Husni. 2002. Pengaruh Perbedaan Warna Wadah terhadap Pertumbuhan dan Kelangsungan Hidup Udang Galah (Marcobrachium rosenbegii (de Man). [Skripsi]. Bogor: Fakultas Perikanan dan Ilmu Kelautan, Institut Pertanian Bogor

Imanpoor MR, Abdollahi M. 2001. Effect of light intensity on growth, stress response and skin color of juvenile Caspian kutum (Rtilus frisii Kutum). Global veterinaria 6(2): 118-125

Kimbal JW. 1998. Biologi Jilid 2. Erlangga. Jakarta

Muslih K, Adiwilaga EM, Adiwiboeo S. 2014. Pengaruh Penambangan Timah terhadap Keanekaragaman Ikan Sungai dan Kearifan Lokal Masyarakat di Kabupaten Bangka. LIMNOTEK Perairan Darat Tropis di Indonesia 21(1): 52-63

Nurdin M. 2013. Perbedaan Lama Penyinaran dan Intensitas Cahaya Terhadap Pertumbuhan serta Sintasan Benih Ikan Tengadak (Barbonymus schwanenfeldii). Tesis. Bogor: Institut Pertanian Bogor

Nurdin M, Nirmala K, Widiyati A. 2015. Kajian Perbedaan Lama Penyinaran dan Intensitas Cahaya terhadap Pertumbuhan Serta Sintasan Benih Ikan Tengadak Barbonymus schwanenfeldii. Jurnal Riset Akuakultur 10(3): 371-378

Nurhidayat, Ragil K, Idil A. 2017. Kelangsungan Hidup dan Pertumbuhan Ikan Cardinal Tetra Paracheirodon axelrodi pada Warna Wadah Pemeliharaan Berbeda. LIMNOTEK
Perairan Darat Tropis di Indonesia 24(1): 15-25

Pratama DR, Maharani HW, Yulianto H. 2018. Pengaruh Warna Wadah Pemeliharaan terhadap Peningkatan Intensitas Warna Ikan Guppy (Poecillia reticulata). Jurnal Rekayasa dan Teknologi Budidaya Perairan 2(1): 776781

Rahmawati R, Cindelaras S, Kusrini E. 2016. Keragaan Pertumbuhan Dan Warna Ikan Wild Betta (Betta sp.) dengan Rekayasa Intensitas Cahaya Dan Warna Latar. Jurnal Riset Akuakultur 11(2): 155-162

Said DS, Supyawati WD, Noortiningsih. 2005. Pengaruh Jenis Pakan dan Kondisi Cahaya terhadap Penampilan Warna Ikan Pelangi Merah Glossolepis incises jantan. Jurnal Ikhtiologi Indonesia 5(2): 61-67

Soebjakto S. 2020. KKP Targetkan Produksi Ikan Hias 1,8 Miliar Ekor. Tempo, 23 Januari 2020 15:31, page 1

Strand A, Alanara A, Staffan F, Magnhagen C. 2007. Effect of Tank Colour and Light Intensity on Feed Intake, Growth Rate and Energy Expenditure of Juvenile Eurasian Pearch Perca fluviatilis L. The Journal of Aquaculture 272(1-4): 312318

Subiyanto R, Ely N, Hariyano, Darto L. 2013. Pemeliharaan Benih Ikan Hias Mandarin (Synchiropus splendidus) dengan Warna Wadah yang Berbeda. Jurnal Teknologi Budidaya Laut 6 (1): 16

Sulistyaningrum W. 2006. Pengaruh Warna Wadah Percobaan terhadap Sintasan dan Pertumbuhan Kuda Laut. Skripsi. Bogor: Fakultas Perikanan dan Ilmu Kelautan, Institut Pertanian Bogor

Suhana. 2017. Ekonomi Ikan Hias Indonesia. Jakarta: Internasional Trade Center

Storebaken T, Hong KN. 1992. Pigmentation of rainbow trout. Aquaculture 100: 209-229

USFWS (2018). Fiveband Barb (Desmopuntius pentazona) Ecological Risk Screening Summary. U.S. Fish and 
Wildlife Service, Web Version $1 / 4 / 2018$.

https://www.fws.gov/fisheries/ANS/erss/ uncertainrisk/ERSS_Desmopuntius_pent azona_January_2018.pdf
Zonneveld N, Huisman EA, Boon JH. 1991. Prinsip-Prinsip Budidaya Ikan. Jakarta: PT Gramedia Pustaka Utama 